\title{
Soil physical properties and soybean productivity in succession to cover crops $^{1}$
}

\author{
Katiely Aline Anschau Deimling ${ }^{2 *} \mathbb{D}$, Edleusa Pereira Seidel ${ }^{2}$, Jean Sérgio Rosset ${ }^{3}$, Marcos Cesar Mottin ${ }^{2}$, \\ Daniela da Rocha Herrmann ${ }^{2}$, Amanda Cecato Favorito ${ }^{2}$
}

\author{
$10.1590 / 0034-737 X 201966040010$
}

\begin{abstract}
The objective of this research was to assess soybean productivity in succession to cover crops grown during the winter, in addition to assessing physical properties macroporosity (Ma), microporosity (Mi), total porosity (Pt), soil density (Sd) and aggregate stability by means of the following variables: aggregate stability index, geometric mean diameter and weighted mean diameter after soybean crop cultivation. The experiment was conducted in the municipality of Quatro Pontes, PR, using a randomized-block design with six treatments and four replications. Treatments consisted of soybean crop grown on top of different cover plants' haystack: black oat, black oat + forage turnip, forage turnip, black oat + forage pea, forage pea and control. Significant differences were observed for soil macroporosity and density. At the depth of $0.10 \mathrm{~m}$, the highest Ma was observed in the area with oat and oat + turnip haystack. At other depths, all cover crops were superior to control. Treatments with cover crops were efficient in reducing soil PR. As for soil aggregation, the treatment with pea was superior to control for weighted mean diameter. The treatments with soybean sown after intercropping obtained greater mass, as well as higher productivity.
\end{abstract}

Keywords: green fertilizers, soil aggregation, Glycine max L., production.

\section{INTRODUCTION}

Soybean crops (Glycine max L.) have been standing out in the agricultural sector with their great economic importance, being a Brazilian commodity that contributes to leverage agricultural growth in the country (Brancalião $\&$ Moraes, 2008). According to research by the National Supply Company, soybean had a growth of $1.9 \%$ in planted area, compared to the previous harvest, and a production of 113.9 million tons (Conab, 2017).

In Paraná, the area planted with this oilseed in the 2016/ 2017 harvest totaled 5,249.6 thousand hectares, with average productivity of $3,721 \mathrm{~kg} \mathrm{ha}^{-1}$, while total production was $16 \%$ higher than that of the 2015/2016 harvest (Conab, 2017). Despite increases in crop production, it is known that monoculture linked to an inadequate cultivation of agricultural areas has been causing a process of degradation and consequent reduction in the productive capacity of these areas (Gomide et al., 2011).

To help reverse the physical degradation process the soil goes through, as well as to prevent crops' productivity losses, several soil management practices are recommended, such as direct seeding system (DSS), green fertilization, intercropping, crop rotation, among others (Santos et al., 2008).

The use of green fertilizers can aid in soil recovery, improving physical, chemical and biological conditions, thus allowing commercial crops to develop well, in addition to providing sufficient soil cover so that DSS is consolidated (Suzuki et al., 2007). Crop residues left by cover plants in the soil promote the improvement or maintenance of chemical properties (Casali et al., 2016) and physical properties, with highlight to aggregate

\footnotetext{
Submitted on May $06^{\text {th }}, 2019$ and accepted on August $07^{\text {th }}, 2019$.

${ }^{1}$ This work is part of the dissertation of the first author.

${ }^{2}$ Universidade Estadual do Oeste do Paraná, Centro de Ciências Agrárias, Marechal Cândido Rondon, Brazil. katy_aline@ hotmail.com

${ }^{3}$ Universidade Estadual do Mato Grosso do Sul, Mundo Novo, Mato Grosso do Sul, Brazil.

* Corresponding author: katy_aline@ @otmail.com
} 
stability and soil porosity, besides biological properties (Moraes et al., 2016).

Another limiting factor for crop development is the degradation of the soil structure, which, due to intensive use, causes particles to disaggregate and, consequently, will restrict root growth, leading to poor crop development and decreased productivity (Pedrotti et al., 2001).

Therefore, systems that support or preserve soil aggregation, such as DSS, should be prioritized, and so the latter is consolidated, soil cover is essential, being one of the basic premises of DSS, which can be maintained using green fertilizers during the winter, preceding the summer crop.

\section{MATERIAL AND METHODS}

\section{Experimental design, implementation and data collection}

The research was conducted at a private property located in the municipality of Quatro Pontes, PR. Its geographic coordinates are $54^{\circ} 00^{\prime} 00.5^{\prime \prime} \mathrm{W}$ and $24^{\circ} 34^{\prime} 12.3^{\prime \prime}$ 'S, with an altitude of 420 meters and average slope of $4 \%$. The soil is classified as a clay-textured Eutroferric Red Latosol (Santos et al., 2013). The region's climate type, according to Köppen classification, is Cfa, subtropical, humid and mesothermal (Caviglione et al., 2000).

The winter crops were planted mechanically using 45 , 15 and $80 \mathrm{Kg} \mathrm{ha}^{-1}$ of seed, respectively, for forage pea (Pisum sativum L.), cultivar IAPAR 83, forage turnip (Raphanus sativus L.), cultivar IPR 116, and black oat (Avena strigosa S.), cultivar EMBRAPA 139. As for the forage turnip + black oat, and forage pea + black oat intercrops, 5 and $30 \mathrm{~kg} \mathrm{ha}^{-1}, 25 \mathrm{~kg}$ and $30 \mathrm{~kg} \mathrm{ha}^{-1}$ of seeds were used, respectively. No base fertilization was used. The experimental design used was of randomized-block type with six treatments and four replications. Each plot measured $10.0 \mathrm{~m}$ long and $5.0 \mathrm{~m}$ wide, totaling $50 \mathrm{~m}^{2}$.

At 100 days after sowing, the cover plants were managed using $2.75 \mathrm{~kg} \mathrm{ha}^{-1}$ of glyphosate acid equivalent. The soybean crop was planted mechanically on September 23, 2016, and the cultivar seeded was NA 5909 RR (Nidera), with $0.45 \mathrm{~m}$ of spacing in between rows and 14 seeds/ linear meter; base fertilization used $280 \mathrm{~kg} \mathrm{ha}^{-1}$ of the 2-2015 formulation. Phytosanitary treatments were carried out according to the crops' needs, using as a basis Embrapa's technical recommendations and the preventive control of fungal diseases that affect the crop as per local technical recommendation.

\section{Collection and analyses}

Before soybean maturation, at R6 stage, two variables were assessed: plant height and plant population, with 10 replications per plot for both assessments. When the soybean crop reached the harvest point (stage R8), harvest was done and assessments were carried out for number of pods per plant; mass of 1,000 beans (mass mean of 8 subsamples of 100 beans on precision scale, corrected for $13 \%$ of moisture) (Brasil, 2009); and yield (mass produced in the plot corrected to $13 \%$ of moisture, estimating productivity for $\mathrm{kg} \mathrm{ha}^{-1}$ ).

After soybean harvesting, two undisturbed soil samples were collected in each plot to determine macroporosity (Ma), microporosity (Mi), total porosity (Pt) and soil density (Ds). A Uhland auger with a metal cylinder (Kopeck Ring) with a known volume of $0.5 \mathrm{~m}^{3}$ in the layers 0 - 0.1 was used. $0.1-0.2$ and $0.2-0.3$ and $0.3-0.4 \mathrm{~m}$. Ma, Mi and $\mathrm{Pt}$ analyzes were performed on a stress table with potential of $-0.006 \mathrm{MPa}$ (light suction), and Ds by the relation between dry soil mass and total collected soil volume (Embrapa, 2011).

The soil's resistance to penetration was evaluated using the Falker digital penetrometer, PenetroLOG-PGL 1020 model, with five determinations per plot. Falker penetrometer data were extracted from digital memory and analyzed at every $0.05 \mathrm{~m}$ depth up to $0.4 \mathrm{~m}$. During sampling, a soil sample was removed from each plot at the 0-0.2 and 0.2-0.4 m layers, for moisture analysis through standard greenhouse method (Embrapa, 2011), which presented on average $0.2 \mathrm{~kg} \mathrm{~kg}^{-1}$ of water.

The stability of moist aggregates was assessed as per methodology described by Kiehl (1979) at the 0-0.2 and 0.2-0.4 m layers. Weighted mean diameter (WMD) (Kiehl, 1979), geometric mean diameter (GMD) (Kemper \& Rosenau, 1986) and aggregate stability index (ASI) were determined (Silva \& Mielniczuk, 1997).

\section{Statistical analysis}

Data were tabulated and subjected to analysis of variance considering a $5 \%$ level of significance for the $\mathrm{F}$ test. When significant, means were compared by the Tukey test at $5 \%$ probability using the statistical software Sisvar (Ferreira, 2011).

\section{RESULTS AND DISCUSSION}

Results obtained in the assessment of soil physical properties after soybean cultivation in succession to different winter cover crops showed significance for macroporosity (Ma) and soil density ( $\mathrm{Sd}$ ) at different layers of assessment (Table 1).

The Ma observed in treatments with oat, oat + turnip, and forage for haystack obtained results higher than those found for control at the 0.0-0.1 m layer (Table 1). For the other evaluation layers, all treatments were superior to control for Ma. This improvement occurs due to the 
aggressive and abundant root system of the cover plants, which cause soil disarrangements and, while decomposing, leave channels (biopores) that contribute to improving the soil's physical quality (Foloni et al., 2006).

The influence of green fertilization on physical characteristics of soils is also due to them promoting greater accumulation of vegetal material deposited on the soil, which raises soil organic matter (SOM) levels, as well as aggregate stability, porosity and moisture retention capacity (Gazolla et al., 2015). Sanchez (2012), in similar study, observed increased Ma at layers of 0.1 to $0.2 \mathrm{~m}$, showing that winter crops acted to promote changes in this physical attribute of the soil, corroborating the results found in this investigation.

Soil microporosity (Mi) and total porosity (Tp) presented no significant differences between soybean cultivation on top of different haystacks, and it can be stated that, for significant changes to happen to these physical properties of the soil, more than a year of cultivation is necessary.

For soil density $(\mathrm{Sd})$, there was difference between treatments at 0.1-0.2 m and 0.2-0.3 m layers; the treatment with oat and forage pea stood out with a smaller $\mathrm{Sd}$, differing from control at the 0.1-0.2 m layer; for the 0.2-0.3 $\mathrm{m}$ layer, in turn, all treatments presented lower $\mathrm{Sd}$ values compared to control's (Table 1).

For the superficial layer and the deepest layer of assessment, no significant differences were found between treatments used (Table 1). For the soil surface layer, it was possible, in some cases, for DSS, to find higher values than those of conventional systems, but, over the years, SOM accumulation tends to reduce this density (Stone \& Silveira, 2001), which may justify the superficial layer not presenting differences between treatments.

Continuous use of direct seeding systems can alter soil density at superficial layers, which could impair the proper development of commercial crops; however, when cover crops are used, because the root system causes the organic descompaction of the soil, besides improving soil structure, crop productivity ends up being favored (Silveira et al., 2008).

When it comes to the soil's penetration resistance $(\operatorname{Pr})$, significant difference $(\mathrm{p}<0.05)$ was found between treatments used for depths assessed. For depths of 0.10 to $0.20 \mathrm{~m}$ and $0.4 \mathrm{~m}$, there was difference between treatments compared to control (Figure 1).

Table 1: Average results for soil physical properties with different winter cover plants and depths of evaluation.

Means followed by the same lowercase letter in the line do not differ statistically from each other by the Tukey test at 5\% probability. ns: Not significant

\begin{tabular}{|c|c|c|c|c|c|c|}
\hline \multirow{2}{*}{$\operatorname{Depths}(\mathrm{m})$} & \multicolumn{6}{|c|}{ Macroporosity $\left(\mathrm{m}^{3} \mathrm{~m}^{-3}\right)$} \\
\hline & Oat & Turnip & Pea & Turnip+Oat & Pea+Oat & Control \\
\hline $0,0-0,1$ & $0.1102 \mathrm{a}$ & $0.1032 \mathrm{ab}$ & $0.1069 \mathrm{a}$ & $0.1125 \mathrm{a}$ & $0.1058 \mathrm{ab}$ & $0.0990 \mathrm{~b}$ \\
\hline $0,1-0,2$ & $0.1013 \mathrm{a}$ & $0.1030 \mathrm{a}$ & $0.1031 \mathrm{a}$ & $0.1073 \mathrm{a}$ & $0.1031 \mathrm{a}$ & $0.0903 \mathrm{~b}$ \\
\hline $0,2-0,3$ & $0.0999 \mathrm{a}$ & $0.0997 \mathrm{a}$ & $0.0971 \mathrm{a}$ & $0.1012 \mathrm{a}$ & $0.0993 \mathrm{a}$ & $0.0883 \mathrm{~b}$ \\
\hline \multirow[t]{3}{*}{$0,3-0,4$} & $0.0962 \mathrm{a}$ & $0.0959 \mathrm{a}$ & $0.0956 a$ & $0.0961 \mathrm{a}$ & $0.0962 \mathrm{a}$ & $0.0825 \mathrm{~b}$ \\
\hline & \multicolumn{6}{|c|}{ Microporosity $\left(\mathrm{m}^{3} \mathrm{~m}^{-3}\right)$} \\
\hline & Oat & Turnip & Pea & Turnip+Oat & Pea+Oat & Control \\
\hline $0,0-0,1$ & $0.4325^{\mathrm{ns}}$ & 0.4353 & 0.4278 & $0.4535^{\mathrm{ns}}$ & $0.4636^{\mathrm{ns}}$ & 0.4408 \\
\hline $0,1-0,2$ & 0.4503 & 0.4407 & 0.4698 & $0.4108^{\mathrm{ns}}$ & $0.4659^{\mathrm{ns}}$ & 0.4711 \\
\hline $0,2-0,3$ & 0.4270 & 0.4551 & 0.4907 & $0.4784^{\mathrm{ns}}$ & $0.4750^{\mathrm{ns}}$ & 0.4804 \\
\hline \multirow[t]{3}{*}{$0,3-0,4$} & 0.4544 & 0.4655 & 0.4734 & $0.4529^{\text {ns }}$ & $0.4757^{\mathrm{ns}}$ & 0.4690 \\
\hline & \multicolumn{6}{|c|}{ Total porosity $\left(\mathrm{m}^{3} \mathrm{~m}^{-3}\right)$} \\
\hline & Oat & Turnip & Pea & Turnip+Oat & Pea+Oat & Control \\
\hline $0,0-0,1$ & $0.5427^{\mathrm{ns}}$ & 0.5411 & 0.5362 & 0.5662 & 0.5705 & 0.5398 \\
\hline $0,1-0,2$ & 0.5478 & 0.5443 & 0.5729 & 0.5182 & 0.5690 & 0.5612 \\
\hline $0,2-0,3$ & 0.5286 & 0.5548 & 0.5879 & 0.5797 & 0.5751 & 0.5687 \\
\hline \multirow[t]{3}{*}{$0,3-0,4$} & 0.5391 & 0.5509 & 0.5690 & 0.5490 & 0.5718 & 0.5515 \\
\hline & \multicolumn{6}{|c|}{ Soil density (mg me } \\
\hline & Oat & Turnip & Pea & Turnip+Oat & Pea+Oat & Control \\
\hline $0,0-0,1$ & $1.18^{\mathrm{ns}}$ & 1.18 & 1.13 & 1.19 & 1.19 & 1.12 \\
\hline $0,1-0,2$ & $1.22 \mathrm{a}$ & $1.27 \mathrm{ab}$ & $1.23 \mathrm{ab}$ & $1.25 \mathrm{ab}$ & $1.22 \mathrm{a}$ & $1.37 \mathrm{~b}$ \\
\hline $0,2-0,3$ & $1.25 \mathrm{a}$ & $1.32 \mathrm{a}$ & $1.28 \mathrm{a}$ & $1.34 \mathrm{a}$ & $1.26 \mathrm{a}$ & $1.48 \mathrm{~b}$ \\
\hline $0,3-0,4$ & $1.25^{\mathrm{ns}}$ & 1.37 & 1.27 & 1.29 & 1.26 & 1.35 \\
\hline
\end{tabular}

Rev. Ceres, Viçosa, v. 66, n.4, p. 316-322, jul/aug, 2019 
For the depth of $0.1 \mathrm{~m}$, the treatment with the oat + turnip intercrop was the only one that did not differ from control (Figure 1), a fact that is related to the turnip's root system, which causes soil particles to compress, resulting in temporary compaction at the site, which is reversed after its complete decomposition. At the depths of 0.15 and 0.2 $\mathrm{m}$, the soil underneath the haystack of forage turnip in monoculture and the pea + oat intercrop showed lower Pr values (2.09 and 2.46 MPa, respectively), differing from control (3.76 e $3.97 \mathrm{MPa})$, as shown in Figure 1.

Silva et al. (2002) found that 2.0 MPa of penetration resistance was a restrictive condition to soybean's root and shoot growth. According to Merotto Junior \& Mundstock (1999), a soil with Pr varying from 1 to $3.5 \mathrm{MPa}$ may hinder the development and growth of crops' root systems, affecting their production negatively, results that may explain the lower productivity of this research's soybean crop, especially when it comes to control, for which Pr values stood above $3.5 \mathrm{MPa}$ (Figure 1).

For the $0.05 \mathrm{~m}$ and $0.25-0.35 \mathrm{~m}$ depths, all treatments were similar, with no statistical differences between them. For the superficial layer, higher organic matter levels lessen the compaction state of the soil; for the $0.25-0.35 \mathrm{~m}$ layer, in turn, this fact may be related to the root system of the cover plants and the soybean that were not yet completely decomposed, and may have influenced the results. For the last assessed layer of $0.40 \mathrm{~m}$, the cultivation of soybeans under the haystack of oat in monoculture differed from control and from the treatment in which soybean was cultivated under forage turnip haystack.

Regarding aggregate stability, a significant difference $(\mathrm{p}<0.05)$ was observed between treatments studied. For the 0.0-0.2 m layer, difference was found between treatments used for weighted mean diameter (WMD); the soybean crop sown over haystack of forage pea in monoculture showed the highest WMD $(2.77 \mathrm{~mm})$, being the only treatment that differed from soybean sown on top of fallow (control) (2.25 mm) (Table 2).

The use of cover crops before soybean sowing favored soil aggregation (Table 2). The lower soil aggregation underneath fallow is related to a lower accumulation of organic matter, which favors a reduction in aggregation, as reported by Vezzani \& Mielniczuk (2011) and can be observed in control (Table 2).

Santos et al. (2012) verified that, at the 0-0.1 m layer, all cover plants provided higher values for WMD compared to those at the 0.1-0.2 m layer, and emphasized the importance of plants' root system in the process of aggregation of soil particles. A satisfactory root growth can increment organic matter along the soil profile, which stabilizes aggregates and reduces the soil's susceptibility to compaction (Santos et al., 2011), which ensures the sustainability of agricultural systems over time.

According to Vezzani \& Mielniczuk (2011), organic matter influences the formation and stabilization of aggregates, and there are studies that confirm the

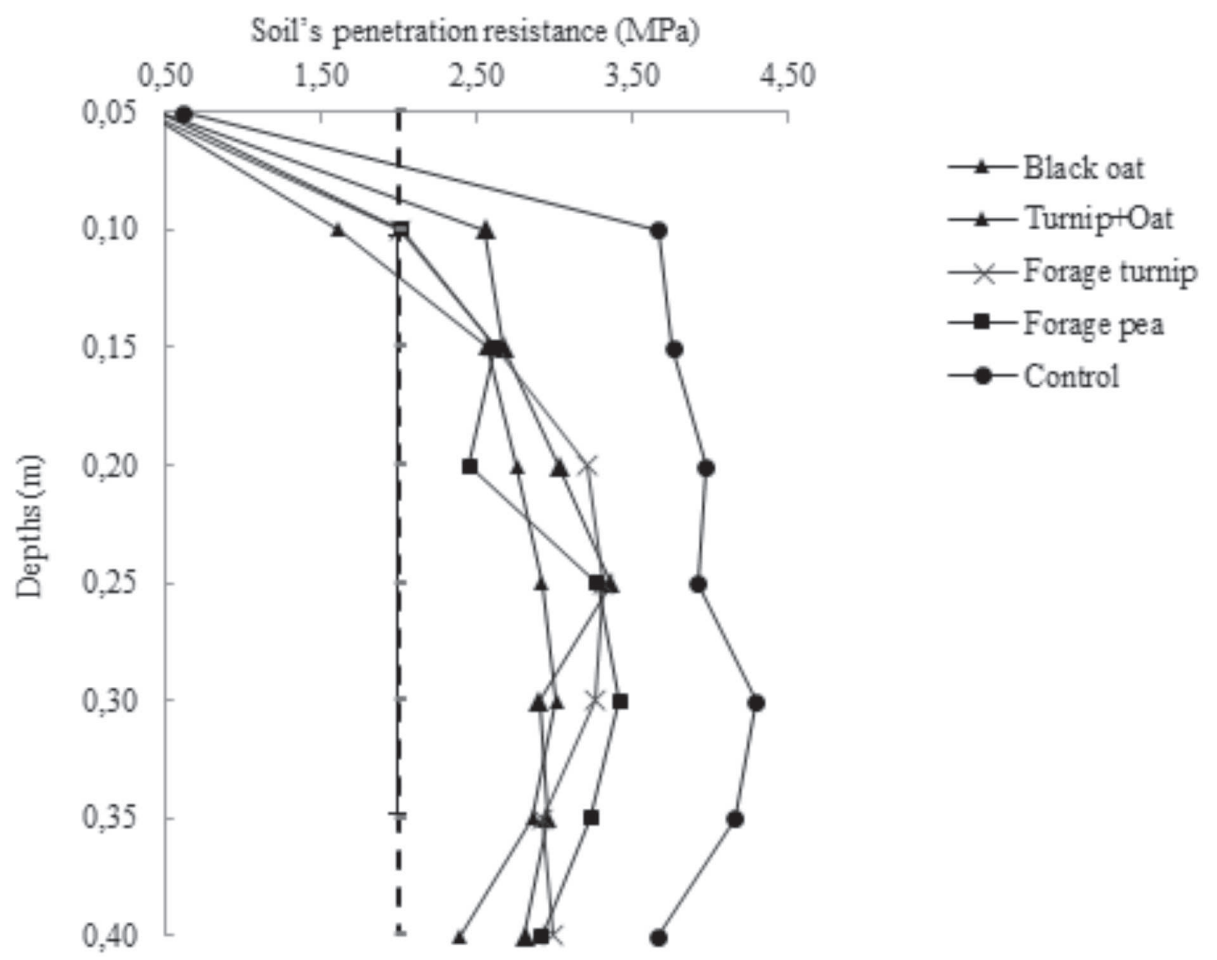

Figure 1: Average results for soil resistance to penetration with soybean sowing after cultivation of winter cover crops at different depths of evaluation. 
correlation between organic matter and soil aggregation, stating that the higher the OM levels the higher the stability of the soil structure (Fontana et al., 2010; Portugal et al., 2010).

Mean results for production components and productivity of soybean crop in succession to different cover crops are presented in Table 3. There was effect of soybean sown under the haystack of cover crops cultivated in winter for mass of 1.000 beans and productivity. For plant population, plant height and number of pods per plant there were no differences between treatments.

It can be stated, based on the results of plants per linear meter, that the different haystacks did not influence the germination and initial development of soybean seedlings. The lowest productivity $\left(4.25 \mathrm{Mg} \mathrm{ha}^{-1}\right)$ and mass of 1.000 beans (202.7 $\mathrm{g}$ ) were obtained in the control treatment (fallow), differing statistically from the other treatments; however, there was no statistical difference between cover crops (Table 3), and these results are consistent, as the mass of 1.000 beans is directly related to the crop's total productivity.

Soybean cultivated under haystack of cover plants presented a superior productivity of approximately $13 \%$ compared to control (fallow), being directly related to the heaviest mass of 1,000 beans. The mean productivity observed was higher than $4.0 \mathrm{Mg} \mathrm{ha}^{-1}$ and is consistent with the means obtained for the Western Paraná region, around 3.8 to $4.0 \mathrm{Mg} \mathrm{ha}^{-1}$ (Conab, 2017).

The lowest productivity was found in the area that was fallowed during the winter, being equal to the area cultivated with forage turnip in the winter $\left(4.64 \mathrm{Mg} \mathrm{ha}^{-1}\right)$, while the other treatments were superior and did not differ from each other (Table 3).

In similar study, Nicoloso et al. (2008) obtained higher soybean yields using cover crops with the oat + forage turnip intercrop in relation to control; due mainly to the higher percentage of soil cover promoted by this intercrop, results that corroborate with those found in this

Table 2: Weighted average diameter (WMD), geometric mean diameter (DMG), and aggregate stability index (ASI) after soybean cultivation (2016/2017 crop) under mulch of winter cover crops in different strata of evaluation

\begin{tabular}{llll}
\hline Treatment & WMD $(\mathbf{m m})$ & GMD $(\mathbf{m m})$ & ASI $(\boldsymbol{\%})$ \\
\hline $0.0-0.2 \mathrm{~m}$ & & & $98.64^{\mathrm{ns}}$ \\
\hline Oat & $2.36 \mathrm{ab}$ & $1.35 \mathrm{~ns}$ & 98.03 \\
Turnip & $2.72 \mathrm{ab}$ & 1.74 & 98.08 \\
Pea & $2.77 \mathrm{a}$ & 1.73 & 98.26 \\
Turnip + Oat & $2.37 \mathrm{ab}$ & 1.39 & 99.58 \\
Pea + Oat & $2.47 \mathrm{ab}$ & 1.46 & 97.61 \\
Control & $2.25 \mathrm{~b}$ & 1.20 & 98.89 ns \\
\hline $0.2-0.4 \mathrm{~m}$ & & & 98.66 \\
Oat & $2.34^{\mathrm{ns}}$ & $1.38 \mathrm{~ns}$ & 98.78 \\
Turnip & 2.62 & 1.64 & 98.27 \\
Pea & 2.69 & 1.63 & 98.47 \\
Turnip + Oat & 2.46 & 1.37 & $96.87^{\mathrm{s}}$ \\
Pea + Oat & 2.69 & 1.61 & 1.24 \\
Control & 2.25 & $\mathrm{p}$ & $\mathrm{p}$ \\
\hline
\end{tabular}

Means followed by the same lowercase letter in the column do not differ statistically from each other by the Tukey test at 5\% probability. ns: Not significant.

Table 3: Average results for soy production and productivity components (crop 2016/2017) after growing under different winter cover crops

\begin{tabular}{|c|c|c|c|c|c|}
\hline \multirow{2}{*}{ Cover crops } & \multirow[t]{2}{*}{ Number of pods } & \multirow{2}{*}{$\begin{array}{c}\text { Plant height } \\
\mathbf{c m} \\
\end{array}$} & \multirow{2}{*}{ Plant population } & \multirow{2}{*}{$\begin{array}{c}\text { Mass of } 1.000 \text { bean } \\
\mathrm{g} \\
\end{array}$} & \multirow{2}{*}{$\begin{array}{c}\text { Productivity } \\
\text { ton }^{\text {ha }}{ }^{-1} \\
\end{array}$} \\
\hline & & & & & \\
\hline Oat & $71^{\mathrm{ns}}$ & $85.3^{\mathrm{ns}}$ & $11.9^{\mathrm{ns}}$ & $234.7 \mathrm{ab}$ & $4.77 \mathrm{a}$ \\
\hline Turnip & 80 & 75.5 & 12.1 & $221.0 \mathrm{ab}$ & $4.64 \mathrm{ab}$ \\
\hline Pea & 74 & 80.1 & 12.3 & $257.7 \mathrm{a}$ & $4.84 \mathrm{a}$ \\
\hline Turnip+Oat & 78 & 77.4 & 12.2 & $250.0 \mathrm{a}$ & $4.84 \mathrm{a}$ \\
\hline Pea+Oat & 77 & 75.5 & 11.6 & $244.7 \mathrm{a}$ & $4.75 \mathrm{a}$ \\
\hline Control & 69 & 73.4 & 11.5 & $202.7 \mathrm{~b}$ & $4.25 \mathrm{~b}$ \\
\hline
\end{tabular}

Averages followed by the same lowercase letter in the column do not differ from each other by the Tukey test at 5\% probability. ns: Not Significant.

Rev. Ceres, Viçosa, v. 66, n.4, p. 316-322, jul/aug, 2019 
investigation. However, Debiasi et al. (2010) did not find any difference in soybean yield in succession to cover crops when compared to fallow system.

Increased productivity of commercial crops in succession to use of cover crops also increases the addition of residues to the soil, accumulating them at the surface and causing an increase in SOM, which improves soil properties along crops. Thus, it can be stated that the cover crops cultivated before the soybean crop promoted benefits to the soil's physical properties and, consequently, led to a better condition for soybean development, raising its yielding compared to fallow.

\section{CONCLUSIONS}

Soybean sowing on top of cover crops in winter proved to be capable of increasing crop productivity compared to soybean sown on fallow.

Accumulation of vegetal material deposited on the soil by both cover crops and soybean haystack after harvest favors the soil's physical properties, promoting improvements in macroporosity, soil density, roots' penetration resistance, and favoring the presence of more stable and larger aggregates, improving soil structure and, consequently, the development of successive crops.

\section{AKNOWLEDGEMENTS, FINANCIAL SUPPORT AND FULL DISCLOSURET}

Capes, for the scholarship granted.

There are no conflicts of interest in the conduct and publication of the work.

\section{REFERENCES}

Brancalião SR \& Moraes MH (2008) Alterações de alguns atributos físicos e das frações húmicas de um Nitossolo Vermelho na sucessão milheto-soja em sistema plantio direto. Revista Brasileira de Ciência do Solo, 32:393-404.

Brasil (2009) Ministério da Agricultura, Pecuária e Abastecimento. Manual de Análise Sanitária de Sementes. Brasília, Ministério da Agricultura, Pecuária e Abastecimento. 200p.

Casali CA, Tiecher T, Kaminski J, Santos DR, Calegari A \& Piccin R (2016) Benefícios do uso de plantas de cobertura de solo na ciclagem de fósforo. In: Tiecher T (Ed.) Manejo e conservação do solo e da água em pequenas propriedades rurais no sul do Brasil: práticas alternativas de manejo visando a conservação do solo e da água. Porto Alegre, UFRGS. p.23-33.

Caviglione JH, Kiihl LRB, Caramor PH \& Oliveira D (2000) Cartas Climáticas do Paraná. Londrina, IAPAR. CD-ROM.

Conab - Companhia Nacional de Abastecimento (2017) Acompanhamento da safra brasileira de grãos. Terceiro levantamento/ setembro 2017, safra 2016/2017. Brasília, Conab. 158p.

Debiasi H, Levien R, Trein CR, Conte O \& Kamimura KM (2010) Produtividade de soja e milho após coberturas de inverno e descompactação mecânica do solo. Pesquisa Agropecuária Brasileira, 45:603-612.
Embrapa - Empresa Brasileira de Pesquisa Agropecuária (2011) Manual de métodos de análises de solo. $2^{\text {a }}$ edição. Rio de Janeiro, Embrapa. 225p.

Ferreira DF (2011) Sisvar: A computer statistical analysis system. Ciência e Agrotecnologia, 35:1039-1042.

Foloni JSS, Lima SL \& Bull LT (2006) Crescimento aéreo e radicular da soja e de plantas de cobertura em camadas compactadas de solo. Revista Brasileira de Ciência do Solo, 30:49-57.

Fontana A, Brito RJ, Pereira MG \& Los A (2010) Índices de agregação e a relação com as substâncias húmicas em Latossolos e Argissolos de tabuleiros costeiros, Campos dos Goytacazes, RJ. Revista Brasileira de Ciências Agrárias, 5:291-297.

Gazolla PR, Guareschi RF, Perin A, Pereira MG \& Rossi CQ (2015) Frações da matéria orgânica do solo sob pastagem, sistema plantio direto e integração lavoura-pecuária. Semina, 36:693-704.

Gomide PHO, Silva MLN \& Soares CRFS (2011) Atributos físicos, químicos e biológicos do solo em ambientes de voçorocas no município de Lavras - MG. Revista Brasileira Ciência do Solo, $35: 567-577$

Kemper WD \& Rosenau RC (1986) Aggregate stability and size distribution. In: Klute A (Ed.) Methods of soil analysis. Madison, American Society of Agronomy. p.425-442.

Kiehl EJ (1979) Manual de edafologia: relação solo planta. São Paulo, Agronômica Ceres. 422p.

Merotto Junior A \& Mundstock CM (1999) Wheat root growth as affected by soil strength. Revista Brasileira de Ciência do Solo, 23:197-202.

Moraes MT, Debiasi H, Franchin JC \& Silva VR (2016) Benefícios das plantas de cobertura sobre as propriedades físicas do solo. In: Tiecher T (Ed.) Manejo e conservação do solo e da água em pequenas propriedades rurais no sul do Brasil: práticas alternativas de manejo visando a conservação do solo e da água. Porto Alegre, UFRGS. p.34-48.

Nicoloso RS, Amado TJC, Schneider S, Lanzanova ME, Girardello VC \& Bragagnolo J (2008) Eficiência da escarificação mecânica e biológica na melhoria dos atributos físicos de um Latossolo muito argiloso e no incremento do rendimento de soja. Revista Brasileira de Ciência do Solo, 32:1735-1742.

Pedrotti A, Pauletto EA, Gomes AS, Turatti AL \& Crestana S (2001) Sistemas de cultivo de arroz irrigado e a compactação de um Planossolo. Pesquisa Agropecuária Brasileira, 36:709-715.

Portugal AF, Juncksh I, Schaefer CERG \& Neves JCL (2010) Estabilidade de agregados em Argissolo sob diferentes usos, comparado com mata. Revista Ceres, 57:545-553.

Sanchez E (2012) Propriedades físicas do solo e produtividade de soja em sucessão a plantas de cobertura de inverno. Dissertação de Mestrado. Universidade Estadual do Centro-Oeste, Guarapuava. 59p.

Santos HP, Lhamby JCB, Prestes AM \& Lima MR (2008) Efeito de manejos de solo e de rotação de culturas de inverno no rendimento e doenças de trigo. Bragantia, 35:335-347.

Santos GG, Marchão RL, Silva EM, Silveira PM \& Becquer T (2011) Qualidade física do solo sob sistemas de integração lavoura-pecuária. Pesquisa Agropecuária Brasileira, 46:1339-1348.

Santos GG, Silveira PM, Marchão RL, Petter FA \& Becquer T (2012) Atributos químicos e estabilidade de agregados sob diferentes culturas de cobertura em Latossolo do Cerrado. Revista Brasileira de Engenharia Agrícola e Ambiental, 16:1171-1178. 
Santos HG, Almeida JA, Lumbreras JF, Anjos LHC, Coelho MR, Jacomine PKT, Cunha TJF \& Oliveira VA (2013) Sistema Brasileiro de Classificação de Solos. $3^{\text {a }}$ ed. Brasília, Empresa Brasileira de Pesquisa Agropecuária. 353p.

Silva IF \& Mielniczuk J (1997) Avaliação do estado de agregação do solo afetado pelo uso agrícola. Revista Brasileira de Ciência do Solo, 21:313-319.

Silva AP, Tormena CA \& Imhoff S (2002) Intervalo hídrico ótimo. In: Moraes MH, Müller MML \& Foloni JSS (Eds.) Qualidade física do solo: métodos de estudo-sistemas de preparo e manejo do solo. Jaboticabal, Funep. p.01-18.
Silveira PM, Stone LF, Alves JRJ \& Silva JG (2008) Efeitos do manejo do solo sob plantio direto e de culturas na densidade e porosidade de um Latossolo. Bioscience Journal, 24:53-59.

Stone LF \& Silveira PM (2001) Efeitos do sistema de preparo e da rotação de culturas na porosidade e densidade do solo. Revista Brasileira de Ciência do Solo, 25:395-401.

Suzuki LEAS, Alves MC \& Suzuki LGAS (2007) Rendimento do feijoeiro influenciado por sistemas de manejo em um Latossolo Vermelho de Cerrado. Acta Scientiarum Agronomy, 29:121126.

Vezzani FM \& Mielniczuk J (2011) Agregação e estoque de carbono em Argissolo submetido a diferentes práticas de manejo agrícola. Revista Brasileira de Ciência do Solo, 35:213-223. 